\title{
DETERMINANTS OF CROWDFUNDING SUCCESS IN CENTRAL AND EASTERN EUROPEAN COUNTRIES
}

\author{
Marija Šimić Šarić*
}

Received: 12. 1. 2021

Preliminary communication

Accepted: 2. 11. 2021

UDC 658.14-059.2

DOI https://doi.org/10.30924/mjcmi.26.2.6

\begin{abstract}
As an alternative way of financing, crowdfunding has been growing rapidly since the last financial crisis in 2008. The number of launched projects has increased, but the number of successful projects remains low. Little is known about what leads to success in this field, especially in Central and Eastern European (CEE) countries where the determinants of crowdfunding

projects from CEE countries, I examine factors influencing the probability of project success. The analyzed sample of projects shows that the number of backers and mean contribution are positively correlated with the probability of campaign success, while a higher project goal lowers the probability of success. Project duration is not a statistically significant success factor.
\end{abstract} campaign success for projects are not identifi$e d$. Therefore, the article focuses on identifying determinants of crowdfunding campaign success for projects from CEE countries. Based on the dataset from Kickstarter, consisting of 473

\section{INTRODUCTION}

Venture capital and business angels are considered alternative ways of financing young, unquoted companies and innovative projects. During the global financial crisis in 2008, venture capitalists intensified their investment criteria as well as business angels. Consequently, the financial gap for young, innovative companies and projects increased. Crowdfunding appeared as an answer to this situation. It is defined as a provision of small amounts of money by a large number of individuals for different needs (cultural, sport-related, technological, or business) through the mobile phone or online platform (Belleflamme, Lambert and Schwinebacher, 2013; World Bank, 2013; Bethlendi and Végh, 2014;

Keywords: crowdfunding, crowdfunding campaign, determinants of success, Central and Eastern Europe

Kirby and Worner, 2014; GPFI, 2016; Jenik, Lyman and Nava, 2017; Delivorias, 2017; European Commision, 2018). Crowdfunding has recently gained in importance around the world. The total crowdfunding volume worldwide in 2015 was 34.4 billion USD, while in 2012 the amount was 2.7 billion USD. This means that the market has grown by $1174 \%$ in 3 years. In Europe 4.2 billion EUR were raised through crowdfunding in 2015 (European Commission, 2016) and 0.735 billion in 2012 (European Commission, 2014). The market increased by $471 \%$. In Central and Eastern European countries the total online alternative finance market volume in 2016 was 217.07 million EUR, while in 2015 it was 60.73 million EUR. The market has grown by $257.43 \%$.

\footnotetext{
* Marija Šimić Šarić, PhD, Assistant professor, University of Split/Faculty of Economics, Business and Tourism, Cvite Fiskovića 5, 21000 Split, Croatia, Phone: ++ 38521430 764; Fax: ++ 38521430 701, E-mail: msimic@efst.hr
} 


\section{Journal of Contemporary Management Issues}

Despite the significant growth of crowdfunding a significant problem has emerged - a high percentage of failed campaigns - as many as $81 \%$ (Lukkarinen, Teich, Wallenius and Wallenius, 2016; Forbes and Schaefer, 2017). To increase the effectiveness of campaigns researchers are trying to identify success drivers of crowdfunding campaigns (Giudici, Guerini, and Rossi Lamastra, 2013; Mollick, 2014; Crosetto and Regner, 2014; Cordova, Dolci, and Gianfrante, 2015; Lukkarinen et al., 2016; Kraus et al., 2016; Šoltés and Štofa, 2016; Ullah and Zhou, 2020). Most of these researchers come from developed countries and the investigated campaigns are of the same origin.

This study aims to identify the determinants of success for crowdfunding campaigns from CEE countries.

For this purpose, we used a dataset from Kickstarter (Webrobots, 2018), which is the world's largest funding platform (Kickstarter, 2018), for the period from June 2010 to February 2018, in which 473 campaigns from CEE countries were launched. The paper has two main contributions to the existing literature. The first is the analysis of descriptive patterns for crowdfunding campaigns from CEE countries, which shows that $52.6 \%$ of projects were successful. The analysis of pledge level histograms shows that campaign failures happen by a large margin, while successful projects collect only a small amount over their goal, which is in line with Mollick's findings (2014). The success rate for each country is also calculated and commented on. The second contribution lies in the analysis of determinants affecting the success of crowdfunding campaigns from CEE countries. For this purpose, logistic regression was conducted with the probability of campaign success as a dependent variable, which is regressed on the following independent variables: number of backers, mean contribution, project goal and duration. In the empirical part, three separate regressions were performed: for all projects, for small projects (goal below 5000 USD), and for large projects (goal over 5000 USD). The results of the empirical analysis show that number of backers and mean contribution positively affect the probability of success. On the other hand, increased funding goal is negatively correlated with campaign success, while campaign duration has no significant influence on the probability of project success. Success determinants are the same for all 3 regressions showing that they do not depend on the funding goal.

The remainder of the paper is organized as follows. Section 2 defines crowdfunding and contains a related literature review. Section 3 describes research methodology, while results are presented in section 4 . Section 5 provides the discussion, while the conclusion is given in section 6 .

\section{LITERATURE REVIEW}

\subsection{Definition of crowdfunding}

Crowdfunding as global, new phenomenon emerged at the time of the global financial crisis in 2008 (World Bank, 2013; Rossi, 2014; Dibrova, 2016; Dushnitsky, 2016). The reasons for the rapid growth of crowdfunding are based on two arguments (Đurđenić, 2017):

- In that period, entrepreneurs had the problem of access to financial resources from banks (banking loans), capital from family and friends was insufficient, capital from capital markets was reduced, as was the capital provided by business angels.

- Simultaneously, World Wide Web 2.0 was created, which contributed to the development of social media. 
Crowdfunding represents the provision of small amounts of money by a large number of individuals for different needs (cultural, sport-related, technological, or business) through the mobile phone or online platform (Belleflame et al., 2013, World bank, 2013, Bethlendi and Végh, 2014; GPFI, 2016; Jenik et al., 2017; Kirby and Worner, 2014; Delivorias, 2017; European Commision, 2018). According to Dibrova (2016, p. 40) crowdfunding is "a new method of financing, based on an intermediary (Internet platform), which links backers/ investors, who are ordinary people willing to invest small amounts into favorable projects, to entrepreneurs/start-ups, which usually represent brave new ideas and have problems with attracting finance using other channels". Furthermore, crowdfunding is defined as "the process of taking a project or business, in need of investment, and asking a large group of people, which is usually the public, to supply this investment" (Forbes and Schaefer, 2017, p. 399).

Depending on what investors receive in return for their contributions, it is possible to distinguish different types of crowdfunding (Manigart, Standaert, Cellewaert and Devigne, 2013; World Bank, 2013; CrowdfundingHub, 2016; Zhang, Wardop, Ziegler, Lui, Burton, James and Garvey, 2016; Delivorias, 2017):

- Donation-based crowdfunding (no reward is received for contribution),

- Reward-based crowdfunding (goods and services are received in exchange for contribution),

- Lending-based crowdfunding (interest payments are received for the contribution)

- Equity-based crowdfunding (shares in the venture are received for the contribution).

Looking at the numbers, the total alternative finance market volume in CEE countries in 2016 amounted to 217.07 million EUR, which presented an increase of $257.43 \%$ compared to the previous year (Figure 1).

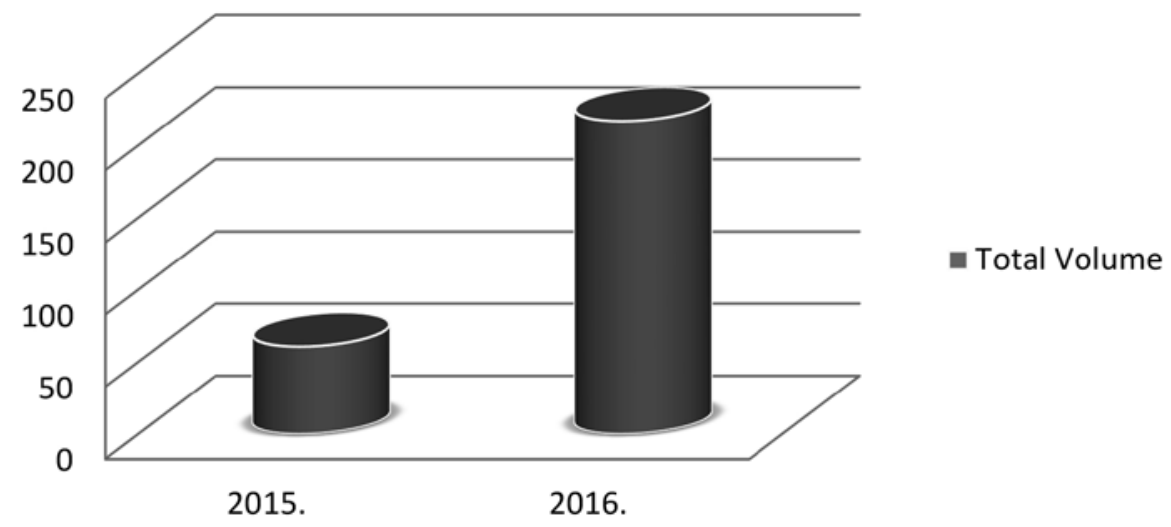

Figure 1. Total alternative finance market volumes for CEE countries ${ }^{1}$

Source: Author, according to Ziegl, Shneor, Garvey, Wenzlaff, Yerolemou, Hao, and Zhang (2017).

\footnotetext{
1 CEE countries are: Albania, Bulgaria, Croatia, Czech Republic, Estonia, Hungary, Latvia, Lithuania, Poland, Romania, Slovakia and Slovenia. Data for Croatia and Abania for 2015. are not available.
} 


\section{Journal of Contemporary Management Issues}

Figure 2 shows the value of the alternative finance market for each CEE country individually. There are large differences between the countries with Estonia as the leading country with the value of the market of 82.48 million EUR in 2016, followed by Poland (38.14 million EUR), Czech
Republic (31.43 million EUR), Latvia (27.16 million EUR), and Lithuania (26.45 million EUR). Slovakia, Slovenia, Albania, Croatia, Bulgaria, Hungary, and Romania together have the value of the market of 11.68 million EUR.

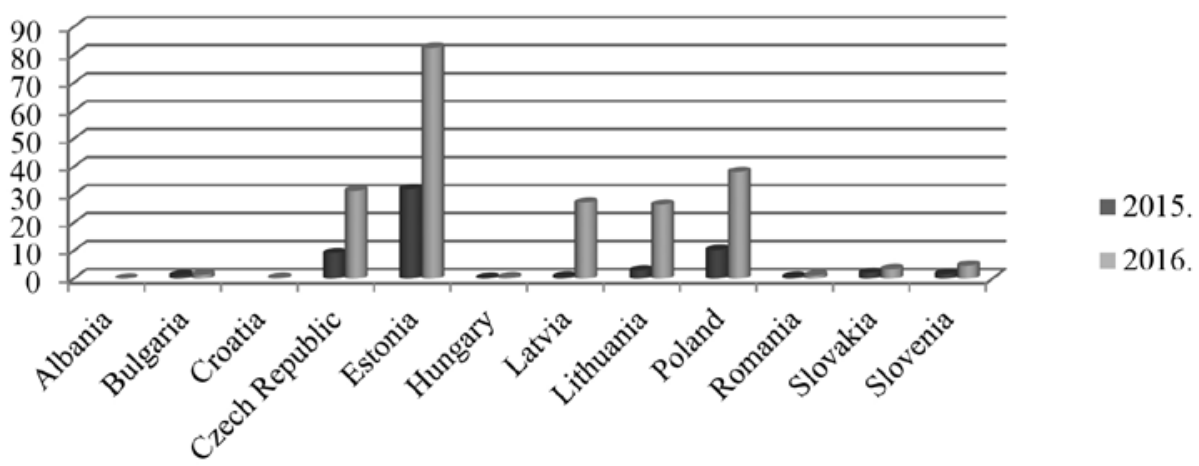

Figure 2. Total alternative finance market volumes for each CEE country

Source: Author, according to Ziegl, Shneor, Garvey, Wenzlaff, Yerolemou, Hao, and Zhang (2017).

\subsection{Determinants of crowdfunding campaign success - empirical studies}

Since 2011, crowdfunding has been recording a significant, exponential growth (Forbes and Schaefer, 2017) in terms of the number of projects, number of platforms and number of total raised capital (Dushnitsky, 2016). Despite the significant growth of crowdfunding a major problem has emerged. - a high percentage of failed campaigns. According to Lukkarinen et al. (2016) and Forbes and Schaefer (2017) the percentage of failure is as high as $81 \%$, while Gałkiewizc and Gałkiewizc (2018) pointed out the percent of $64 \%$ on Kickstarter. To increase the effectiveness of campaigns researchers are trying to identify success drivers of crowdfunding campaigns (Giudici et al., 2013; Mollick, 2014; Crosetto and Regner, 2014; Cordova et al., 2015; Lukkarinen et al., 2016; Kraus et al., 2016; Šoltés and Štofa, 2016), although the academic literature related to factors of success of crowdfunding projects is still fairly limited (Krause et al., 2016).

Mollick (2014) conducted an exploratory empirical study of projects on Kickstarter for the period between 2009 and July 2012. Variables used in his study are project goal, funding level, backers, pledge/backers, Facebook friends of founders, category, updates, comments, and duration. The findings show that positive determinants of the project success are personal networks (proxied by the number of Facebook friends) and signals of high project quality (proxied by the availability of a video that describes the project and spelling errors in the project description), while the negative ones are project's targeted amount and project duration. Furthermore, projects with very high funding goals are unlikely to achieve success. It is necessary to point out that Mollick (2014) eliminated foreign Kickstarter projects, while this study will focus on foreign 
Kickstarter projects, more precisely, projects from CEE countries.

Giudici et al. (2013) worked on a sample of 669 projects from Kickstarter.com, which were started in 2012. They followed the projects from their inception to closure in order to identify the determinants of crowdfunding campaign success by focusing on internal social capital. According to them, positive predictors of success are the number of early backers and the percentage of target capital pledged early in the project campaign, while target capital is negatively related to success. Furthermore, campaign duration, number of external links and the number of images and videos do not have significant coefficients. Crosetto and Regner (2014) analyzed funding dynamics, pledgers' motivations, and project success determinants of a crowdfunding project from the German platform Startnext, from October 2010 until February 10th, 2014. The results show that the target amount of a project and the funding duration are negatively correlated with success, while the quality indicators of a project (number of videos/ images, blog updates, recommendation by Startnext) with its potential funders are success determinants.

Cordova et al. (2015) studied 1127 technology projects from four crowdfunding platforms (Kickstarter, Ulule, Eppela and Indiegogo) in order to explain factors for fundraising success and for the overfunding of a successful project. According to them, higher project funding goal is negatively correlated with success, while project duration and the dollar amount contribution per day are positively related to success. Lukkarinen et al. (2016) analyzed data from a leading crowdfunding platform in Northern Europe in order to find whether the investment criteria set by venture capitalists and business angels are appropriate for a successful equity crowdfunding campaign. The results show that venture capital and business angels' investment criteria are not important for success in equity crowdfunding. The factors related to success are pre-selected crowdfunding campaign characteristics and the utilization of private and public networks.

Vulkan, Asterbo and Fernández Sierra (2015) analyzed 636 campaigns from SEEDRS, an equity crowdfunding platform from the United Kingdom. According to them, a successful campaign depends either on many backers or on one who is ready to provide a large pledge. It is also necessary to start strong. Bednarz et al. (2017) analyzed the factors of crowdfunding development in 10 Central and Eastern countries (Bulgaria, Czech Republic, Estonia, Hungary, Latvia, Lithuania, Poland, Romania, Slovak Republic, and Slovenia) in the period from 2007 till 2015 in terms of GDP per capita and the population age structure. According to them, the value of GDP per capita is not correlated with the amount of alternative online financing per capita, while there is a significant impact of population age structure on the increase of financing through crowdfunding. In their paper, Šoltés and Štofa (2016) studied crowdfunding in the Czech Republic and Slovakia. They found that goal, average pledge, and the number of donors are significant for the project's success, but they did not describe each of the variables.

According to the previously reviewed studies and the best of the author's knowledge, there is no study about the determinants of success of crowdfunding projects encompassing all CEE countries. Accordingly, this gap will be filled by the current study conducted on the CEE countries' projects by applying the most frequently used variables of success in the 


\section{Journal of Contemporary Management Issues}

literature like the number of backers, mean contribution, project goal, and project duration.

\section{METHODS}

Since this study deals with crowdfunding projects in CEE, data from the Kickstarter platform were used because it includes a larger number of countries of interest than other platforms. Dataset consists of 473 finished Kickstarter crowdfunding campaigns from June 2010 to February 2018 located in one of the following CEE countries: Albania, Bulgaria, Croatia, Czech Republic, Estonia, Hungary, Latvia, Lithuania, Poland, Romania, Slovakia, and Slovenia. Data were extracted by parsing the dataset available at Webrobots (2018) in CSV and JSON format. Statistical analysis was performed in IBM SPSS software. I filtered out projects with one of the following characteristics: canceled, suspended, and live. According to Mollick (2014), campaigns with goals below 100 USD and above one million USD are considered unrealistic trials and eliminated from the analysis.

We selected the following independent variables from the literature:

- Number of backers: The number of funders contributing to the project

- Mean contribution: The individual pledges of backers are not known, but this variable is the amount of money raised divided by the number of backers or the mean pledge per backer.

- Project goal: logarithm of financing goal (requested amount). This variable directly influences the campaign's success. Selection of appropriate value is essential to find a balance between a low goal that is more likely to be collected, but may lead to project non-delivery, and too high goals that are less likely to be achieved.

- Duration: duration of the crowdfunding campaign (expressed in number of days)

Project success is chosen as a dependent dichotomous variable that refers to campaign success or failure. Since Kickstarter supports all-or-nothing model, where the founder receives investments only if the collected amount exceeds the requested amount, successful projects are those funded over the set goal.

\section{RESULTS}

Descriptive statistics for all projects in the dataset are summarized in Table 1. The mean value for the number of backers per project is 363.67 backers. The maximum value is 35384 , the minimum is 0 backers and the standard deviation is 1840.91 . The data show how large the span for the number of backers per project is. According to the mean contribution, the mean value per project is 70.49 USD, with the minimum of 0 USD and the maximum of 709.80 USD. Mean contributions show that backers invest a small amount of money per project, which is in line with the theoretical assumptions. The mean value of a project's goal is 21175.14 USD, with the minimum of 150 USD and the maximum of 620000 USD. The standard deviation is 49406.69 USD that shows a significant difference among individual projects. The shortest project lasted for 3.61 days, while the longest one lasted for 89.23 days and the mean duration was 33.71 days.

Due to the significant difference in project goals, the projects were classified into 
small projects (goal below 5000 USD) and large projects (goal above 5000 USD). It was necessary to categorize the projects from the sample into two subgroups according to the category of the amount of funds requested (project goal) since the underlying model for 200 USD campaign can be significantly different than the model for 100000 USD projects (Mollick, 2014; Cordova, Dolci, and Gianfrante 2015). Table 1 summarizes descriptive statistics for small and large projects.

Table 1. Summary statistics for all projects

\begin{tabular}{|l|l|c|c|c|c|}
\hline & Variable & Mean & $\begin{array}{c}\text { Standard } \\
\text { Deviation }\end{array}$ & Min & Max \\
\hline \multirow{4}{*}{ All projects } & Number of backers & 363.67 & 1840.91 & 0 & 35384 \\
\cline { 2 - 6 } & Mean contribution (USD) & 70.49 & 81.08 & 0 & 709.80 \\
\cline { 2 - 6 } & Project goal (USD) & 21175.14 & 49406.69 & 150 & 620000 \\
\cline { 2 - 6 } & Duration (days) & 33.71 & 12.0 & 3.61 & 89.23 \\
\hline \multirow{4}{*}{$\begin{array}{l}\text { Small projects } \\
\text { project goal below } \\
\text { 5000 USD) }\end{array}$} & Number of backers & 43.58 & 131.67 & 0 & 1733 \\
\cline { 2 - 6 } & Mean contribution (USD) & 57.14 & 60.82 & 0 & 500 \\
\cline { 2 - 6 } & Project goal (USD) & 1923.24 & 1189.92 & 150 & 4500 \\
\cline { 2 - 6 } & Duration (days) & 30.24 & 12.24 & 3.61 & 89.23 \\
\hline \multirow{3}{*}{$\begin{array}{l}\text { Large projects } \\
\text { project goal over } \\
\text { 5000 USD) }\end{array}$} & Number of backers & 590.17 & 2378.89 & 0 & 35384 \\
\cline { 2 - 6 } & Mean contribution (USD) & 79.93 & 91.73 & 0 & 709.80 \\
\cline { 2 - 6 } & Project goal (USD) & 34797.42 & 61025.04 & 5000 & 620000 \\
\cline { 2 - 6 } & Duration (days) & 36.17 & 11.22 & 8 & 62.01 \\
\hline
\end{tabular}

Source: Research results

Table 1 shows that the mean value for the number of backers for small projects is 43.58 , the minimum is 0 and the maximum is 1733 backers. The standard deviation is 131.67. These projects have a lower mean number of backers (43.58) in comparison to the value obtained for all projects (363.67) as well as a lower maximum number of backers (1733 vs 35384$)$. The average mean contribution is equal to $57.14 \mathrm{USD}$, the maximum value is 500 USD and the minimum is 0 . The mean value for the project goal is 57.14 USD with the maximum of 4500 USD and the minimum of 150 USD. In this situation the standard deviation is equal to 1189.92 USD. In terms of project duration, the average project duration for small projects is 30.24 days, similar to the duration for all projects (33,71 days). It is necessary to point out that long project duration suggests that the project leader is not sure about the success of his project.
The data in Table 1 also show the statistics for large projects. The average number of backers equals 590.17 backers, where the minimum is 0 and the maximum is 35384 backers. In this situation a considerable difference is visible in the number of backers per project, considering the standard deviation of 2378.89 backers. The mean contribution equals 79.93 USD with the maximum of 709.80 USD and the minimum of 0 USD. The average project goal is $34,797.42$ USD, with the maximum of 620,000 USD and the minimum of 5,000 USD. According to the standard deviation of $61,025.04$ USD, the projects are quite heterogeneous. The mean value for the variable duration of the projects is 36.17 days, with the maximum of 62.01 days and the minimum of 8 days. The results also show that project duration should not exceed more than one month. 


\section{Journal of Contemporary Management Issues}

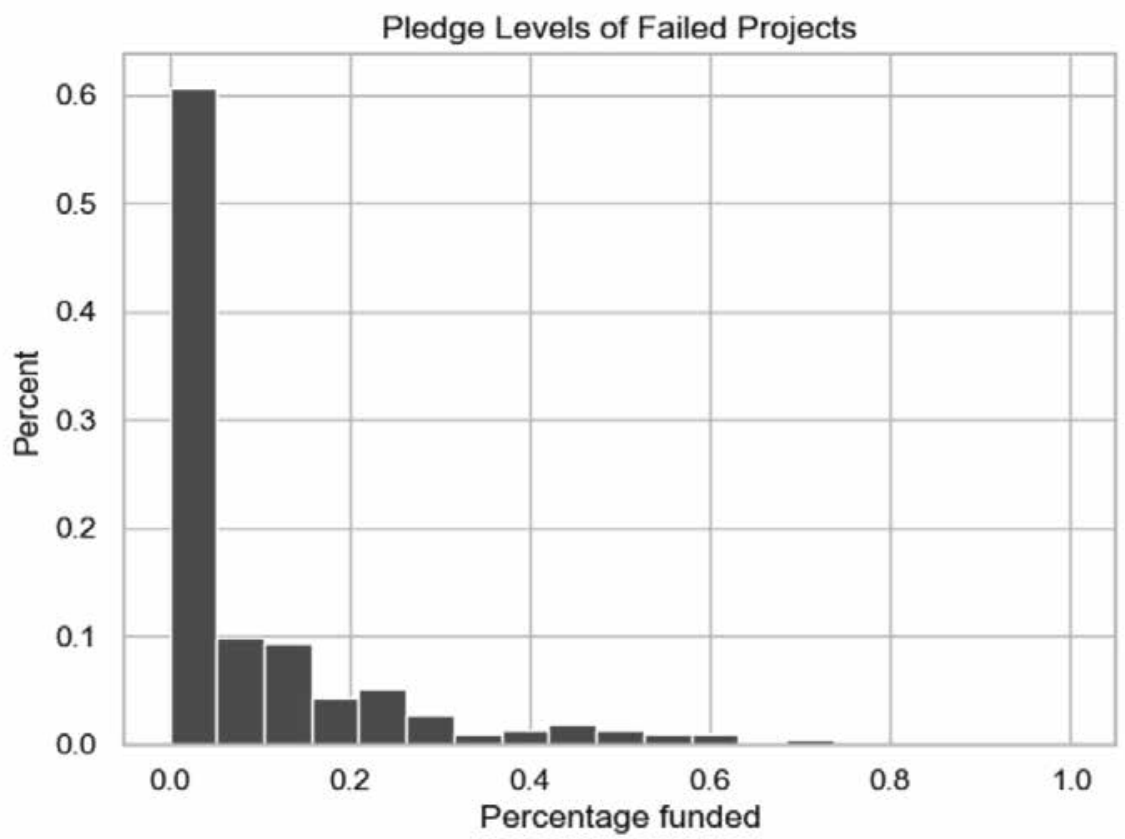

Figure 3. Histogram of pledge levels of failed projects for all categories

Source: Research results

To determine the factors affecting the success of crowdfunding projects, descriptive patterns were analyzed followed by logistic regression on previously mentioned independent variables. The success rate for 473 campaigns from CEE countries equals $54.8 \%$, i.e., overall $54.8 \%$ of 473 campaigns from CEE were successful. Furthermore, histograms of pledge levels for failed and successful projects are visible from Figures 3 and 4. It can be seen that unsuccessful projects that fail by large margins are those where the mean collected amount is $8.5 \%$ of the goal and only $7.5 \%$ of projects receive more than $30 \%$ of the goal. On the other hand, successful projects reach a relatively small amount over their goal. More precisely, $15.1 \%$ of these projects raise less than $3 \%$ over their goal and $64.4 \%$ are above $10 \%$ over goal. 


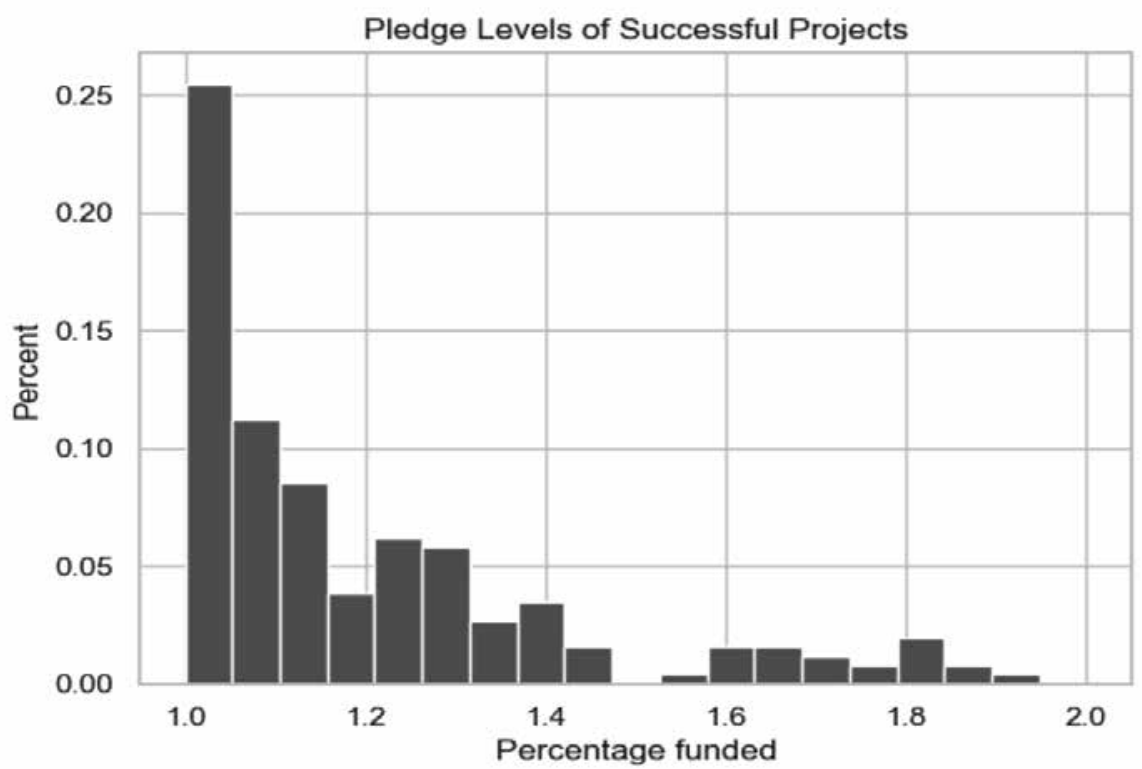

Figure 4. Histogram of pledge levels of successful projects for all categories Source: Research results

Figure 5 shows the percentage of successful projects for each country. The highest success rates are reported in the Czech
Republic (70\%) and Slovenia (63.3\%), while Slovakia has the lowest percentage of successful projects $(18.2 \%)$

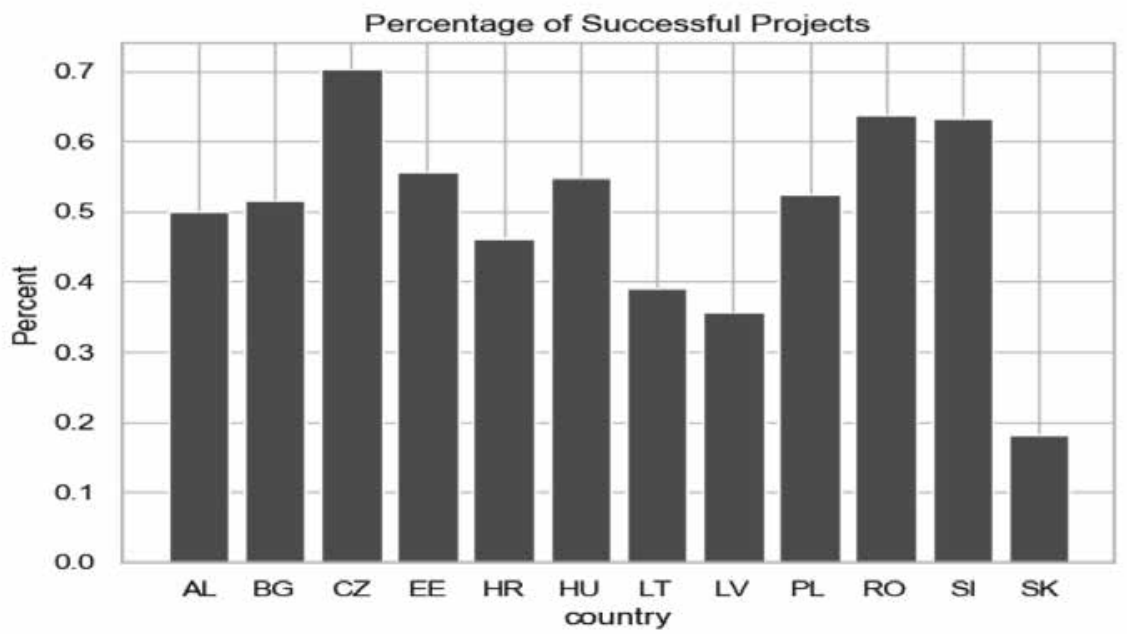

Figure 5. Percentage of successful projects for each country from Central and Eastern Europe Source: Research results 


\section{Journal of Contemporary Management Issues}

Data analysis using binary logistic regression is employed to detect variables influencing the success probability of crowdfunding campaigns in CEE countries. Unlike the linear regression model that is suitable for estimating a continuous dependent variable like funding amount, binary logistic regression is appropriate for dichotomous (binary) output variable project success. It estimates the conditional probability of output, that is probability of campaign success for given input variables. Three separate logistic regressions were performed. The first regression is for all projects in the dataset, the second is for projects with goal below 5000 USD and the third is for projects with goal above 5000 USD. Results are presented in Table 2.

Table 2. Predictors of project success

\begin{tabular}{|l|c|c|c|}
\hline Variables & All projects & $\begin{array}{c}\text { Projects below } \\
\text { 5000 USD }\end{array}$ & $\begin{array}{c}\text { Projects above } \\
\text { 5000 USD }\end{array}$ \\
\hline Number of backers & $0.0308^{* *}$ & $0.1976^{* *}$ & $0.0452^{* *}$ \\
$(0.004)$ & $0.0318^{* *}$ & $0.1495^{* *}$ & $(0.009)$ \\
\hline \multirow{2}{*}{ Mean contribution } & $(0.004)$ & $(0.036)$ & $0.0432^{* *}$ \\
& -0.0067 & -0.0044 & $(0.009)$ \\
\hline \multirow{2}{*}{ Duration } & $(0.014)$ & $(0.033)$ & 0.0518 \\
& $-4.786^{* *}$ & $-12.1141^{* *}$ & $(0.033)$ \\
\hline \multirow{2}{*}{ Log of project goal } & $(0.565)$ & $(3.514)$ & $-15,223^{* *}$ \\
& $13.4672^{* *}$ & $25.5853^{* *}$ & $5.296)$ \\
\hline \multirow{2}{*}{ Constant } & $(1.681)$ & $(7.740)$ & $(11.437)$ \\
\hline
\end{tabular}

Note: Standard errors are in parentheses. ${ }^{*} \mathrm{p}<0.05 ;{ }^{* *} \mathrm{p}<0.01$

Source: Research results.

For all projects, small, as well as large ones (Table 2), the number of backers, mean contribution and project goal significantly affect the probability of campaign success, while duration is not statistically significant. An increasing number of backers and mean contribution is positively associated with success probability. Log of project goal has a strong negative influence on success.

\section{DISCUSSION}

The first contribution of the proposed paper is the analysis of description patterns for crowdfunding campaigns from CEE countries. It has been shown that the overall success rate for these countries $(54.8 \%)$ is similar to the value obtained for Kickstarter campaigns from the US (48.1\%) (Mollick, 2014) and higher than the success rate of $19 \%$ reported in Lukkarinen et al. (2016) and Forbes and Schaefer (2017). Cordova, Dolci, and Gianfrante (2015) found a success rate of $30 \%$ for technology projects extracted from Indiegogo and Italian-based Eppela platforms, which is also lower than the success rate obtained in this study. Histograms of pledge levels for failed and successful projects match patterns for Kickstarter US campaigns presented in Mollick (2014) which confirms that for campaigns in CEE countries "failures happen by large amounts, successes by small amounts". Regarding individual countries, the highest percentage of successful projects $(70 \%)$ is reported for campaigns from 
the Czech Republic and this value is significantly higher than the result reported for US projects in Mollick (2014). On the other side, the lowest success rate of $18.2 \%$ is found for Slovakia which is similar to the percentage reported in (Lukkarinen et al., 2016, Forbes and Schaefer, 2017)

The second contribution is the identification of success factors for CEE countries. Logistic regressions performed for 3 project categories (small, large and all projects) consistently show that the number of backers and mean contribution have a positive influence on success. This result is in line with conclusions given in Cordova, Dolci, and Gianfrante (2015).

Log of project goal negatively impacts the probability of campaign success which is in accordance with other findings (Mollick, 2014; Cordova, Dolci, and Gianfrante, 2015; Lukkarinen et al., 2016; Crosetto and Regner,2014; Giudici, Guerini and Rossi Lamastra, 2013). Furthermore, the results show that campaign duration is not a significant factor for project success. This finding is different from the conclusions given in Mollick (2014), where for large projects a longer duration has a negative impact on success because a longer duration can result from the lack of confidence. Similarly, Lukkarinen et al. (2016) found that campaign duration has negative influence on the amount raised and the number of investors. Analysis conducted on projects from German platform Starnext by Crosetto and Regner (2014) also shows that campaign duration is negatively correlated with project success. On the other hand, Cordova, Dolci, and Gianfrante (2015) found that for technological projects a higher number of campaign days increases the likelihood of the project to be successful.

The presented crowdfunding success factors for Central and Eastern Europe countries mainly correspond to findings made by other authors that investigated campaigns from different countries including Italy in Giudici, Guerini and Rossi Lamastra (2013), Germany in Crosetto and Regner (2014)) and Northern Europe in Lukkarinen et al., 2016, as well as overall Kickstarter projects in Mollick (2014). Furthermore, similar conclusions are derived for technology projects in Cordova, Dolci, and Gianfrante (2015). However, some findings differ from those found for other countries or Kickstarter projects in general. More specifically, it was found that duration is not statistically significant, which can be emphasized as a specific feature for projects from Central and Eastern European countries. All 3 conducted regressions (all, small and large projects) give the same result, which shows that success drivers do not depend on the target amount. This finding differs from the conclusion for technological projects given in Cordova, Dolci, and Gianfrante (2015), where success drivers for all projects and projects over 5000 USD are not the same. The number of backers and mean contribution have influence when all projects are taken into account, while these variables are not significant for large projects. Although Mollick (2014) states that "the underlying models for USD100 projects and USD 100,000 projects are likely very different", this is not supported by our analysis. Therefore, it can be pointed out that success factors for projects from Central and Eastern European Countries remain the same regardless of the target amount.

\section{CONCLUSION}

Since the last financial crisis in 2008, crowdfunding has been growing continuously. Likewise, the number of crowdfunding platforms and the number of launched 


\section{Journal of Contemporary Management Issues}

projects has increased. Despite the growing number of launched projects, the number of successful projects is very low. What leads to success in this field, especially in Central and Eastern European (CEE) countries is unknown. Therefore, this paper identified the success determinants for crowdfunding campaigns from Central and Eastern European countries.

According to the level histograms for failed and successful projects, the pattern shows that failed campaigns collected only a small percentage of the target amount, while successful projects collected only a small amount over their goal. The success rate is $54.8 \%$, which is higher than the rates reported for campaigns from Northern Europe. Analysis performed for individual countries shows that the Czech Republic and Slovenia have the highest success rates (70\% and 63.3\%), while Slovakia has the lowest percentage of successful projects $(18.2 \%)$. Furthermore, logistic regression analysis shows that the number of backers and mean contribution increase the probability of campaign success, while higher projects goal has a negative influence. This result confirms findings for campaigns from the US, Germany, and Northern Europe. It was also found that project duration is not a statistically significant factor for project success.

It can be concluded that for campaigns from Central and Eastern European countries, three out of four chosen explanatory variables represent success determinants that are identical to those identified for campaigns from other countries and regions (US, Germany, Northern Europe). Unlike in other studies, the duration does not influence projects' success and this finding is thus emphasized as a specific feature of the projects from Central and Eastern European countries. It has also been shown that success determinants are the same when separate regressions are performed for projects with small financing goal, projects with large goal and all projects.

The limitation of the proposed analysis is related to the relatively small number of features used for regression. This will be addressed in future research by including more explanatory variables, especially those indicating project quality like spelling errors or sentiment analysis of project description. Another limitation is the fact that the number of backers, mean contribution and project duration are bound to the time period after project posting when project creators cannot adapt their profiles. Therefore, future studies will focus on success determinants in the preposting phase which would be of great importance for the maximization of project success probability.

\section{REFERENCES}

1. Belleflamme, P., Lambert; Th \& Schwinebacher, A. (2013) Crowdfuding: Tapping the right crowd, Journal of Business Venturing, 1-25.

2. Bednarz, J., Markiewicz, M., \& Ploska, A. (2017). The determinants of crowdfunding development-empirical analysis in the countries of Central and Eastern Europe (No. 70/2017). Institute of Economic Research Working Papers.

3. Bethlendi, A., \& Végh, R. (2014). crowdfunding-could it become a viable option for Hungarian small businesses?. Financial and Economic Review, 13(4), 100-124.

4. Crosetto, P., \& Regner, T. (2014). Crowdfunding: Determinants of success and funding dynamics (No. 2014-035). Jena Economic Research Papers. 
5. Cordova, A., Dolci, J., \& Gianfrate, G. (2015). The determinants of crowdfunding success: evidence from technology projects. Procedia-Social and Behavioral Sciences, 181, 115-124.

6. CrowdfundingHub (2016). Current State of Crowdfunding in Europe, An Overview of the Crowdfunding Industry in more than 25 Countries: Trends, Volumes \& Regulations, Amsterdam, Netherlands, 1-67.

7. Delivorias, A. (2017). Crowdfunding in Europe: Introduction and state of play. Briefing, European Parliamentary Research Service, European Parliament, 1-8.

8. Dibrova, A. (2016). Analysis of crowdfunding in European Union: Performance and perspectives. In Contemporary issues in finance: Current challenges from across Europe. Emerald Group Publishing Limited, 37 - 48

9. Đurđenić, K. (2017). CrowdfundingCroatian legal perspective and comparison to other sources of financing. Public Sector Economics, 41(2), 259-287.

10. European Commission (2018). Crowdfunding in the EU Capital MarketsUnion, available:https:// ec.europa.eu/info/system/files/crowdfunding-report-03052016_en.pdf (accessed on 4.09.2018 )

11. European Commission (2018). Unleashing the potential of Crowdfunding in the European Union, available: http://ec.europa. eu/internal_market/finances/docs/ crowdfunding/140327-communication_en.pdf (accessed on 4.09.2018)

12. European Commission (2018). Crowdfunding, available: https:// ec.europa.eu/info/ business-economy-euro/growth-and-investment/financing-investment/crowdfunding_en\#what-is-crowdfunding (accessed on 22.01.2018).

13. Forbes, H., \& Schaefer, D. (2017). Guidelines for successful crowdfunding. Procedia, 60, 398-403.

14. Gałkiewicz, D. P., Gałkiewicz, M. (2018). Crowdfunding Monitor 2018, An Overview of European Projects Financed on Startnext and Kickstarter Platforms between 2010 and mid-2017. Bermang/Szczecin.

15. Giudici, G., Guerini, M., \& Rossi Lamastra, C. (2013). Why crowdfunding projects can succeed: the role of proponents' individual and territorial social capital. Available at SSRN 2255944.

16. Global Partnership for Financial Inclusion (GPFI), (2016). Global Standard-Setting Bodies and Financial Inclusion: The Evolving Landscape, White Paper. Washington, D.C., 1-76.

17. Jenik, I., Lyman, T., \& Nava, A. (2017). Crowdfunding and financial inclusion. CGAP (Consultative Group to Assist the Poor) working paper, 41.

18. Kirby, E., \& Worner, S. (2014). Crowdfunding: An infant industry growing fast. IOSCO Research Department, 1-63.

19. Kraus, S., Richter, C., Brem, A., Cheng, C. F., \& Chang, M. L. (2016). Strategies for reward-based crowdfunding campaigns. Journal of Innovation \& Knowledge, 1(1), 13-23.

20. Lukkarinen, A., Teich, J. E., Wallenius, H., \& Wallenius, J. (2016). Success drivers of online equity crowdfunding campaigns. Decision Support Systems, 87, 26-38.

21. Manigart, S., Standaert, Th., Cellewaert, V., Devigne, D. (2013). 


\section{Journal of Contemporary Management Issues}

Literature Review on the financing of young innovative ventures, Vlerick Business School, Gent, 1-92.

22. Mollick, E. (2014). The dynamics of crowdfunding: An exploratory study. Journal of Business Venturing, 29(1), 1-16.

23. Rossi, M. (2014). The new ways to raise capital: an exploratory study of crowdfunding. International Journal of Financial Research, 5(2), 8.

24. Statista (2018). Total crowdfunding volume worldwide from 2015 to 2018, available: https://www.statista. $\mathrm{com} /$ statistics/620952/total-crowdfunding-volume-worldwide/ (accessed on 4.09.2018)

25. Šoltés, M., \& Štofa, T. (2016). Crowdfunding-The Case of Slovakia and the Czech Republic. Quality Innovation Prosperity, 20(2), 89-104.

26. Ullah, S., \& Zhou, Y. (2020). Gender, anonymity and team: What determines crowdfunding success on Kickstarter. Journal of Risk and Financial Management, 13(4), 80.
27. Vulkan, N., Åstebro, T., \& Sierra, M. F. (2016). Equity crowdfunding: A new phenomena. Journal of Business Venturing Insights, 5, 37-49.

28. Bank, W. (2013). Crowdfunding's Potential for the Developing World. In info Dev, Finance and Private Sector Development Department. World Bank.

29. Webrobots (2018). Kickstarter datasets, available: https://webrobots. io/kickstarter-datasets (accessed on 21.7.2018.)

30. Zhang, B. Z., Ziegler, T., Garvey, K., Wardrop, R., Lui, A., \& Burton, J. (2016). Sustaining momentum: The 2nd European alternative finance industry report. Available at SSRN 3621306 .

31. Ziegler, T., Shneor, R., Garvey, K., Wenzlaff, K., Yerolemou, N., Hao, R., \& Zhang, B. (2017). The $3^{\text {rd }}$ European Alternative Finance Industry Report, Cambridge Centre for Alternative Finance, University Cambridge Judge Business School, 1-123. 


\title{
DETERMINANTE USPJEŠNOSTI SKUPNOG FINANCIRANJA ZA ZEMLJE SREDNJE I ISTOČNE EUROPE
}

\begin{abstract}
Sažetak
Skupno financiranje, kao alternativni način financiranja, brzo raste od zadnje financijske krize 2008. godine. Broj pokrenutih projekata raste iz godine u godinu, ali, broj uspješnih projekata je vrlo nizak. Malo je toga poznato što je čimbenik uspjeha u ovom području, osobito za zemlje srednje i istočne Europe, gdje determinante uspješnosti kampanja skupnog financiranja nisu identificirane. Stoga se ovaj članak fokusira na indetifikaciju determinanti uspješnosti kampanja skupnog financiranja iz zemalja srednje i istočne Europe. Na temelju Kickstarter baze podataka, koja obuhvaća 473 projekata iz navedenih zemalja, istraženi su faktori koji utječu na vjerojatnost projektnog uspjeha. Analiza provedenih projekata ukazuje kako su broj podržavatelja i prosječni ulog pozitivno povezani s vjerojatnošću uspjeha kampanje, dok viši projektni cilj smanjuje vjerojatnost uspjeha. U istraživanju trajanje projekta nije se pokazalo kao statistički važan faktor uspjeha.
\end{abstract}

Ključne riječi: skupno financiranje, kampanje skupnog financiranja, determinante uspješnosti, srednja i istočna Europa 